\title{
EFEKTIVITAS PENERIMAAN PAJAK BUMI DAN BANGUNAN TERHADAP PENINGKATAN PENDAPATAN ASLI DAERAH KABUPATEN LAMONGAN \\ (Studi Kasus Pada Kantor Pemerintahan Kabupaten Lamongan Periode Tahun 2014 - 2018)
}

\author{
Toto Heru Dwihandoko \\ Program Studi manajemen, Fakultas Ekonomi, \\ Universitas Islam Majapahit \\ Email: totodwihandoko@yahoo.com
}

\begin{abstract}
Tax is the source used to finance a development. One of which is the land and building tax. This study goals to determine (1) the effectiveness of land and building tax revenues in lamongan districts in 2014 until 2018, (2) barriers that impact the effectiveness of land and building tax revenues in the district of 2014 until 2018, (3) Government to overcome barriers that affect the level of tax effectiveness of the earth and buildings in the district lamongan 2014 until 2018.

The method that used in this research is by documentation technique. Data analysis method used in this research is Quantitative Descriptive method. The results shows that: (1) the effectiveness of land and buildings tax revenues in the district of 2014 until 2018 has been very effective, (2) the barriers that impact the effectiveness of tax revenues of land and buildings is difficult to meet taxpayers, And knowledge of taxpayers in paying taxes, (3) efforts to overcome obstacles in the tax revenue of the land and buildings is in cooperation with village rayon coordinator, and held more socialization. The authors provide recommendations to the district revenue department of Lamongan district should more often hold socialization for tax revenue of land and buildings increasing in the years to come.
\end{abstract}

Keywords: property tax, Tax revenue of the earth and banguan in regency of lamongan

Abstrak
Pajak menjadi sumber penerimaan negara yang sedianya digunakan untuk
membiayai beban pengeluaran negara atas pembangunan. Pajak bumi dan
bangunan merupakan salah satu sumber untuk pembiayaan tersebut. penelitian ini
mempunyai beberapa tujuan, antara lain: untuk mengetahui (1) tingkat efektifitas
penerimaan pajak (PBB) di kabupaten lamongan tahun 2014 - 2018, (2) Untuk
mendapatkan pengetahuan atas berbagai hambatan yang terjadi dan berpengaruh
terhadap efektivitas penerimaan pajak (PBB) di kabupaten lamongan tahun 2014
sampai dengan 2018, (3) Untuk mengetahui beragam upaya yang dapat dilakukan
pemerintah Kabupaten Lamongan dalam mengatasi hambatan yang muncul.
Metode yang digunakan penelitian ini adalah dengan teknik dokumentasi. Metode
penelitian ini adalah metode deskriptif Kuantitatif. Penelitian ini menunjukan
hasil bahwa : (1) tingkat efektifitas penerimaan pajak (PBB) Kabupaten
Lamongan tahun 2014 - 2018 sudah sangat efektif, (2) hambatan yang

Bisman (Bisnis dan Manajemen): The Journal Of Business and Management 
mempengaruhi tingkat efektifitas penerimaan pajak bumi dan bangunan adalah sulit ditemuinya wajib pajak, kurangnya kesadaran dan pengetahuan wajib pajak dalam membayar pajak, (3) upaya yang dilakukan untuk mengatasi hambatan dalam pajak (PBB) adalah dengan menjalin kerjasama dengan koordinator rayon desa, dan mengadakan sosialisasi. penulis memberikan rekomendasi kepada Badan Pendapatan daerah kabupaten lamongan hendaknya lebih sering mengadakan sosialisasi agar penerimaan pajak (PBB) dapat meningkat ditahun selanjutnya.

\section{Kata Kunci: Pajak bumi dan banguan, penerimaan Pajak bumi dan bangunan di Kabupaten Lamongan}

\section{PENDAHULUAN}

Berdasarkan "UU No. 28 Tn 2009 tentang pajak daerah dan retribusi daerah" yang baru, bahwa selama ini pungutan Pajak Bumi dan Bangunan (pajak (PBB) dilakukan oleh pemerintah pusat, namun hampir seluruh penerimaannya diserahkan kepada daerah. Namun, mulai tahun 2013 pemungutan pajak (PBB) mulai dialihkan dari pemerintah pusat ke pemerintah daerah.

pajak (PBB) merupakan pajak yang sifatnya kebendaan yang mana besaran pajak dihitung berdasarkan atas keadaan/kondisi dari objek pajak yang berupa tanah/bumi dan/atau berupa bangunan dan tidak ditentukan dengan Keadaan subjek (pembayar) (Erly Suandy, 2005 : 61). Sebagaimana "pasal 1 ayat 1 Undang-Undang Republik Indonesia Nomor 12 Tahun 1985 Bumi diartikan sebagai permukaan bumi dan tubuh bumi yang ada dibawahnya". Sedangkan dalam ayat 2 "bangunan diartikan sebagai konstruksi teknik yang ditanam atau dilekatkan secara tetap pada tanah dan/atau perairan."

Meskipun besaran pajak (PBB) merupakan tagihan pajak yang memiliki nominal relatif kecil dibandingkan pajak-pajak yang dipungut pemerintah pusat lainnya, tetapi dampaknya luas. hal ini disebabkan hasil dari penerimaan tersebut dikembalikan lagi ke daerah yang bersangkutan untuk pembangunan (Prathiwi ,2015).

Efektivitas pajak (PBB) yang dimaksud dalam penelitian ini ketercapaian target pemasukan negara dari pajak (PBB) yang ditetapkan berbanding dengan realisasi oleh Pemerintah Kabupaten Lamongan atas Pajak tersebut. dengan kata lain apakah target atas Pajak yang telah ditetapkan tersebut sudah tercapai/terlaksana dengan baik atau belum. Melihat dari masa pajak sebelumnya, penerimaan Pajak sebagaimana dimaksud sudah efektif, maka peneliti ingin mengetahui apakah pada masa pajak selanjutnya, yakni tahun 2014-2018 juga akan efektif seperti halnya masa pajak sebelumnya atau mengalami penurunan persentasenya.

\section{Rumusan Masalah}

Dalam penjelasan serta uraian latar belakang yang sudah dipaparkan dalam pendahuluan penelitian, maka rumusan masalah yang akan dikupas sebagaimana berikut: 
1. Berapakah efektivitas penerimaan PAJAK (PBB) terhadap peningkatan Pendapatan Asli Daerah (PAD) Kabupaten Lamongan untuk Periode Tahun 2014-2018?

2. Faktor apa saja yang dapat menghambat efektivitas penerimaan PAJAK (PBB) di Kabupaten Lamongan untuk Periode Tahun 2014-2018?

3. Upaya-upaya apa saja yang dapat dilakukan pemerintah Kabupaten Lamongan untuk menanggulangi hambatan yang muncul?

\section{Tujuan Penelitian}

Berdasarkan dari latar belakang dan rumusan masalah diatas, maka dapat dirumuskan pula tujuan penelitiannya, yaitu:

1. Peneliti berkehendak untuk mengetahui efektivitas penerimaan pajak (PBB) terhadap peningkatan penerimaan Pendapatan Asli Daerah (PAD) Kabupaten Lamongan untuk Periode Tahun 2014-2018.

2. Untuk mendapatkan pengetahuan atas berbagai hambatan yang terjadi dan berpengaruh terhadap efektivitas penerimaan pajak (PBB) di Kabupaten Lamongan untuk Periode Tahun 2014-2018.

3. Untuk mengetahui beragam upaya yang dapat dilakukan pemerintah Kabupaten Lamongan dalam mengatasi hambatan yang muncul.

\section{KAJIAN PUSTAKA}

\section{Pengertian Pajak}

Mardiasmo (2016:1) memberikan pengertian atas pajak sebagai iuran wajib dari warga negara yang dibayarkan kepada kas negara, tentunya pembayaran tersebut atas adanya peraturan perundang-undangan (yang sifatnya memaksa) dan tidak mendapatkan feed back berupa apapun secara langsung karena digunakan untuk membiaya beban pengeluaran negara yang bersifat umum.

Menurut Suandy (2013:7) pajak diartikan sebagai kontribusi yang bersifat wajib bagi warga negara kepada negara sebagai hutang orang perorangan atau badan dan sifatnya memaksa berdasarkan peraturan perundang-undangan, wajib pajak tidak mendapatkan timbal balik berupa apapun secara langsung yang mana kontribusi tersebut dapat digunakan negara untuk meningkatkan kemakmuran masyarakat sebesar-besarnya.

Menurut Rahayu (2010:21) pajak bermula dari adanya istilah "ajeg” dalam bahasa jawa yang diartikan sebagai pungutan berkala dan teratur pada waktu tertentu. sejalan dengan rutinitas yang terjadi di masyarakat, istilah tersebut berangsur berubah menjadi pa-ajeg, sehingga pa-ajeg dapat diartikan sebagai tarikan atau pungutan kepada masyarakat yang dilakukan oleh negara secara teratur/rutin terhadap hasil bumi.

\section{Fungsi pajak}

Suandy (2013:12) mengemukakan bahwa pajak memiliki dua fungsi, antara nya yaitu :

1. "Fungsi budgeter yakni upaya memasukan uang sebanyak-banyaknya ke dalam kas negara, untuk selanjutnya digunakan membiayai berbagai beban pengeluaran negar"a. 
2. "Fungsi regulerend yakni fungsi pajak sebagai alat/instrumen untuk mengatur keadaan sosial, ekonomi, sosial, dam politik dalam masyarakat dengan tujuan yang tertentu".

\section{Jenis Pajak}

Prathiwi (2015) mengemukakan bahwa jenis pajak dibedakan menjadi dua kelompok, pengelompokan tersebut yakni:

1. Pajak langsung, yakni pajak yang secara langsung harus dan wajib ditanggung sendiri oleh wajib pajak (WP), tidak dapat dilimpahkan/dialihkan atau dibebankan kepada orang lain. Misalnya : $\mathrm{PPh} /$ pajak penghasilan.

2. Pajak tidak langsung, yakni pajak yang pembayarannnya dapat dilimpahkan/dialihkan atau dibebankan kepada orang lain atau pihak ketiga. Misalnya : PPN/pajak pertambahan nilai.

Sedangkan pemungutan pajak menurut lembaga pemungutnya dibedakan menjadi dua, diantaranya sebagai berikut :

1. Pajak pusat atau pajak daerah, yakni jenis pajak yang mana pemerintah pusat sebagai pemungut pajak dan hasilnya untuk digunakan membiayai keperluan/pengeluaran beban rumah tangga negara yang sifatnya umum. Misanya : PPh, pajak penjualan atas barang mewah, dan PPN,

2. "Pajak daerah, merupakan pajak yang mana pemerintah daerah baik daerah tingkat I / pajak provinsi maupun daerah tingkat II / pajak kabupaten/kota, pajak tersebut selanjutnya akan dipergunakan untuk membiayai beban rumah tangga daerah masing-masing. Misalnya : pajak restoran, pajak bumi dan bangunan, pajak kendaraan bermotor, pajak hiburan, pajak reklame" (Ferdiansyah, dkk : 2018) .

Sedangkan menurut sifatnya pajak dibagi menjadi 2, antaranya sebagai berikut :

1. Pajak subjektif, yaitu pajak yang dasar pengenaannya memperhatikan kondisi/keadaan pribadi dari wajib pajak atau dasar pengenaan pajaknya dengan memperhatikan subjek pajak lainya. Misalnya : $\mathrm{PPh}$.

2. Pajak objektif, yaitu pajak yang pengenanaanya didasarkan atas objeknya yang bisaberupa benda, tempat tinggal, keadaan atau kondisi dari obyek pajak, serta perbuatan yang dapat menimbulkan kewajiban bagi wajib pajak untuk membayar pajak. contoh pajak ini antara lain: PPN dan pajak penjualan atas barang mewah.

\section{Tarif Pajak}

Suandy (2013:67-71) mengemukakan bahwa, salah satu persyaratan dalam melakukan pemungutan pajak adalah pelaksanaanya. dalam pelaksanaan pemungutan pajak harus didasari atas asas keadilan, dengan demikian pemerintah dapat menciptakan keseimbangan sosial dalam masyarakat guna meningkatkan taraf kesejahteraan bagi masyarakat secara keseluruhan. pemungutan tarif pajak tersebut dapat dijadikan cara untuk mewujudkan kadilan. Tarif atas pajak yang lazim dan sudah dikenal wajib pajak seta sudah ditetapkan dapat dikategorikankan 
menjadi empat jenis sebagaimana berikut ini :

1. Tarif tetap, merupakan tarif pajak yang jumlah atau besaran nominalnya tetap meskipun yang menjadi dasar penentuan pengenaan pajaknya berbeda/berubah, dengan kata lain besaran pajak terutang adalah tetap/tidak berubah, Contohnya adalah besaran bea materai yang dikenakan terhadap bilyet giro ataupun cek berapapun nominal dari giro ataupun cek tersebut tetap dikenakan pajak sebesar Rp 500.

2. Tarif proporsional merupakan tarif pajak yang besarannya ditentukan dengan presentase tetap, dengan demikian besarnya pajak terutang berubah sesuai dengan besaran dasar pengenaan pajak. Contoh : tarif PPn yang ditentukan sebesar $10 \%$

3. Tarif progresif merupakan tarif pajak yang presentasinya semakin besar jika dasar pengenaan pajaknya meningkat jumlahnya. contohnya adalah pajak kendaraan bermotor.

4. Tarif degresif, yaitu merupakan tarip pajak dimana presentasenya menjadi semakin kecil apabila dasar pengenaan pajaknya meningkat jumlahnya.

\section{Pengertian Pajak Bumi dan Bangunan}

Pajak (PBB) menurut Suandy (2013:59) merupakan pajak negara yang dikenakan pada obyek pajak yang mana obyek pajak tersebut adalah bumi dan/atau bangunan. Berdasarkan perundang-undangan terkait pajak (PBB) diartikan sebagai "pajak yang bersifat kebendaan dalam artian besaran pajak terutang ditentukan oleh keadaan objek yaitu bumi/tanah dan atau bangunan yang mana Keadaan subjek (siapa yang membayar) tidak ikut menentukan besarnya pajak" (UU No. 12 Th 1985 jo. UU No. 12 Th 1994).

\section{Dasar Hukum Pajak (PBB)}

Pajak (PBB) diatur dalam "Undang-Undang Nomor 12 tahun 1985 dan telah diubah dengan Undang-Undang Nomor 12 tahun 1994”.

\section{Objek Pajak (PBB)}

Objek pajak (PBB) menurut Saputro, dkk (2016) adalah Bumi dan bumi beserta bangunan diatasnya. Pengklasifikasian atas objek Bumi dan bumi beserta bangunan diatasnya berdasarkan pada pengelompokan atas bumi dan bumi beserta bangunan diatasnya menurut nilai jual obyek pajak (NJOP). NJOP tersebut sedianya dijadikan sebagai pedoman dalam penghitungan besaran pajak terutang.

Menurut Suandy (2013:59) objek pajak (PBB) adalah bumi dan/ atau banguanan. "Bumi diartikan sebagai permukaan bumi dan tubuh bumi yang ada dibawahnya" (pasal 1 ayat 1 UU No. 12 Th 1985). yang masuk dalam kategori obyek pajaknya antara lain: kebun, tanah, sawah, ladang, pekarangan, tambang, dan lain-lain. Sedangkan dalam ayat 2 "UU No. 12 Th 1985 bangunan diartikan sebagai konstruksi teknik yang ditanam atau dilekatkan secara tetap pada tanah dan/atau perairan". Contoh: toko/bangunan tempat usaha, Mall/pusat perbelanjaan, rumah tempat tinggal, kolam renang, jalan tol, anjungan minyak lepas pantai, dan lain-lain. 


\section{Dasar Penggenaan PAJAK (PBB)}

Menurut Waluyo (2014:170), dasar pengenaan pajak (PBB) adalah NJOP. Besaran NJOP ditentukan per-lokasi/wilayah dengan mengacu pada keputusan Kepala Kanwil Dirjen Pajak. Penentuan tersebut terlebih dahulu memperhatikan kriterian sebagai berikut:

1. Harga rata-rata dari transaksi perolehan atas bumi atau bumi beserta bangunan yang dilakukan secara wajar,

2. Pembandingan harga dengan objek lain (obyek tersebut harus sejenis) dengan letak berdekatan yang telah diketahui harga jualnya,

3. "Nilai perolehan baru",

4. "Penentuan nilai jual pengganti"

Sedangkan, menurut Tarigan (2013), NJOP adalah "harga rata-rata yang diperoleh dari transaksi jual-beli secara wajar, dan bilamana tidak terdapat adanya transaksi jual beli, maka NJOP dapat ditentukan dengan membandingkan harga dengan objek lain (sejenis), atau nilai perolehan baru, dan NJOP pengganti”.

\section{Pengertian Efektivitas}

Menurut Darmayanti (2014) mengemukakan bahwa suatu organisasi dapat dikatakan berhasil pada umumnya dapat diukur menggunakan konsep efektivitas. Secara terminologi efektif diambil dari kata dasar "efek" dan menunjukkan adanyahubungan kausalitas. Eefektivitas dapat pula diartikan sebagai ketercapaian tujuan sesuai dengan perencanaan yang sudah direncanakan sebelumnya melalui suatu proses kegiatan tertentu.

Menurut Prathiwi Dkk (2015) mengungkapkan bahwa suatu kegiatan atau proses dapat dikatakan efektif jika kegiatan atau proses tersebut sesuai dengan harapan yang dicita-citakan. dua pendapat tersebut dapat diambil kesimpulannya bahwa efektivitas merupakan kegiatan/proses tertentu yang harus dijalankan sebagai bentuk/upaya pencapaian tujuan yang sudah ditentukansebelumnya. Tujuan sebagaimana dimaksud dalam penelitian ini adalah tujuan dari instasi pada pemerintah Kabupaten Lamongan, maka proses pencapaian tujuan tersebut adalah keberhasilan atas pelaksanaan program atau kegiatan sesuai dengan kewenangan, tugas pokok dan fungsi instansi tersebut.

\section{Pengertian Pendapatan Asli Daerah}

Menurut Resmi (2017:8) "Pendapatan Asli Daerah (PAD) merupakan penerimaan asli daerah yang bersumber dari wilayah itu sendiri yang dipungut berdasarkan peraturan daerah yang sudah ditetapkan dan berlaku saat itu". PAD sangat berperan penting, karena besaran PAD ini menjadi tolok ukur kemampuan daerah melakukan pembiayaan sendiri atas kegiatan pemerintahan dan pelaksanaan pembangunan daerahnya. Daerah sepatutnya dapat berperan aktif agar mampu mengoptimalkan penerimaan dari PAD di daerahnya yang mana hal tersebut merupakan perwujudan nyata pelaksanaan otoda (otonomi daerah) yang berasas desentralisasi. 


\section{Kerangka Berfikir}

Pajak merupakan sumber penerimaan negara yang sangat penting dalam meningkatkan pendapatan negara, salah satu jenis pajak tersebut adalah pajak bumi dan bangunan. Agar dapat diketahui efektivitas dari penerimaan pajak (PBB) terhadap peningkatan penerimaan PAD di Kabupaten Lamongan, maka berbagai data yang terkait dengan rencana maupun realisasi penerimaan pajak (PBB) dalam pemungutan pajak (PBB) dikabupaten lamongan sangat dibutuhkan. dari data ini dapat diketahui berbagai informasi terkait hambatan-hambatan yang mempengaruhi efektifitas penerimaan PAJAK (PBB) untuk kemudian dicarikan solusinya.

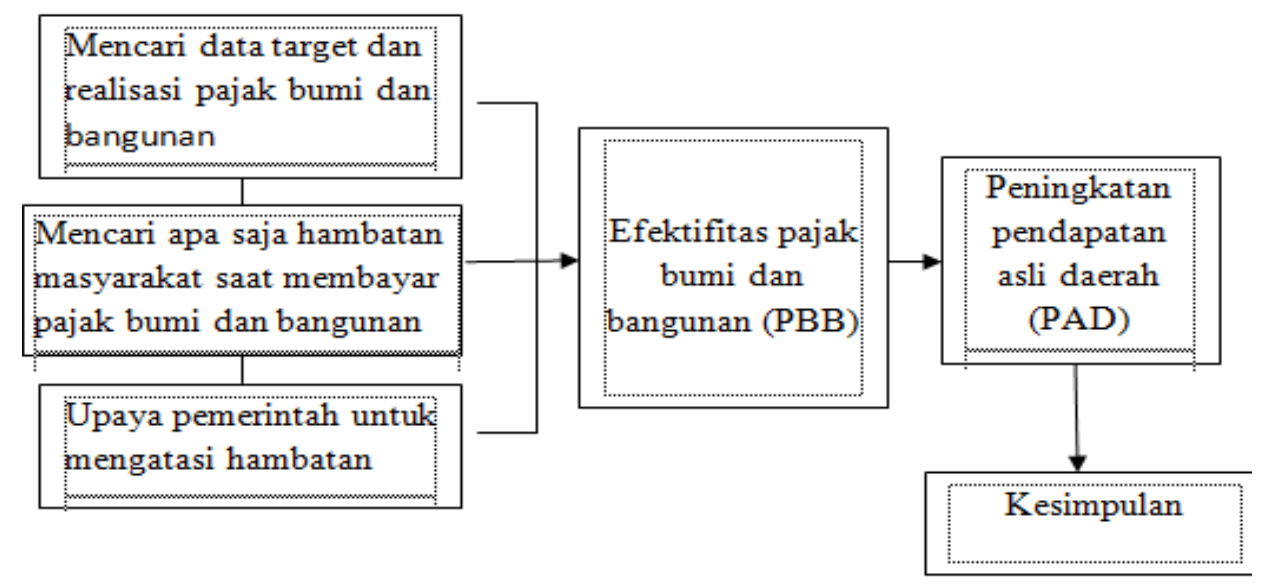

\section{METODELOGI PENELITIAN}

Penelitian ini masuk dalam jenis penelitian deskriptif Kuantitatif. Menurut Efferin dkk (2008:47) Penelitian kuantitatif adalah penelitian yang pengujiannya ditekankan pada teori-teori beserta hipotesis-hipotesis yang ada melalui pengukuran variabel-variabel dalam penelitian yang disajikan dalam bentuk angka untuk dianalisis dengan prosedur statistik permodelan matematis.

\section{Objek Penelitian}

Sesuai dengan judul penelitian ini "efektivitas penerimaan pajak bumi dan bangunan (PBB) periode 2014-2018" maka penelitian mengambil lokasi penelitian pada Kantor Badan Pendapatan Daerah (Bapenda) Kabupaten Lamongan, penelitin ini sendiri bertujuan untuk mengetahui efektivitas pajak (PBB) di Kabupaten Lamongan, untuk mendapatkan pengetahuan atas berbagai hambatan yang terjadi dan berpengaruh terhadap efektivitas penerimaan pajak (PBB) di Kabupaten Lamongan untuk Periode Tahun 2014-2018 dan upaya pemerintah dalam mengatasi hambatan tersebut di Kabupaten Lamongan. penelitian memiliki objek penelitian yang berada di kantor Bapenda Kabupaten Lamongan karena sejak tahun 2013 pajak (PBB) tidak lagi menjadi kewenangan pemerintah pusat sebagai pemungutnya melainkan telah daerah yang bersangkutan (menjadi pajak daerah). 


\section{Populasi}

Sugiyono (2015: 61) menyatakan bahwa "populasi merupakan wilayah generalisasi obyek penelitian yang terdiri atas : objek/subyek yang berkuantitas dan berkarateristik tertentu sesuai dengan yang telah ditetapkan peneliti untuk dipelajari, dianalisa dan kemudian ditarik kesimpulannya guna mencapai tujuan penelitian". Populasi dari penelitian ini adalah Laporan penerimaan pajak (PBB) Pemerintahan Kabupaten Lamongan.

\section{Sampel}

Menurut Sugiyono (2015: 62) sampel adalah "bagian dari populasi dan tentunyan memiliki karakteristik yang dari populasi tersebut". Sampel penelitian ini adalah Laporan penerimaan pajak (PBB) Pemerintahan Kabupaten Lamongan tahun 2014-2018.

\section{Pengambilan Sampel}

Menurut Sugiyono (2015: 62) teknik sampling adalah "teknik pengambilan sampel. Dalam menentukan jumlah sampel penelitian, peneliti memilih non probability sampling dengan metode purposive sampling. Teknik sampling ini didasarkan pada pertimbangan-pertimbangan atau kriteria-kriteria tertentu" (Sugiyono, $2014: 85$ ).

\section{Teknik Pengumpulan Data}

Sumber data penelitian ini adalah data sekunder, Menurut Efferin, dkk (2008:115) Data sekunder merupakan data yang didapat peneliti dari surat kabar, media cetak dan elektronik serta dari berbagai badan pengumpulan data lainya. Dalam penelitian ini untuk mengumpulkan data dengan cara mengumpulkan data dengan cara mengumpulkan teori-teori dan refrensi-refrensi dari buku, data yang diperlukan diantaranya adalah data penerimaan pajak (PBB) dari tahun 2014-2018

\section{Teknik Pengumpulan Data}

Peneliti mengumpulkan data dengan metode Dokumentasi. Dokumentasi merupakan suatu cara dalam mengumpulkan data penelitian baik berupa catatan, ataupun sumber tertulis lainnya seperti halnya buku. Adapun dokumen yang kumpulkan meliputi dokumen terkait target dan realisasi pajak (PBB), hambatanhambatan yang mempengaruhi keefektivan dan strategi pemerintah untuk mengatasi masalah yang timbul pada saat proses pemungutan pajak (PBB) dikabupaten Lamongan. Data tersebut diperoleh dari Bapenda Kabupaten Lamongan.

\section{Metode Analisis Data}

Data penelitian ini dianalisis dengan dengan cara mendeskripsikan atau menggambarkan tingkat keberhasilan pemungutan pajak (PBB) di Kabupaten Lamongan. Langkah untuk menganalisis tingkat pengukuran keberhasialan sebagai berikut: 
1. Rasio atau Analisis Efektifitas

Efektivitas dihitung dengan membandingkan "realisasi penerimaan pajak (PBB) dengan target penerimaan pajak (PBB)". Adapun rumus yang digunakan menurut Saputro, dkk (2016) :

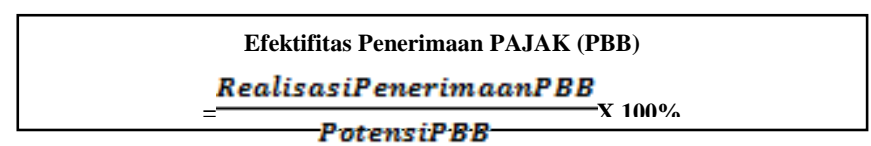

Sumber: Saputro, dkk (2016)

Keterangan :

Potensi pajak (PBB) adalah target penerimaan Pajak Bumi dan Bangunan.

Efektivitas penerimaann PAJAK (PBB) dalam penelitian ini menggunakan kriteria sesuai dengan tabel sebagai berikut :

Klasifikasi Kriteria Nilai Efektivitas

\begin{tabular}{cc}
\hline Presentase & Kriteria \\
\hline DIatas 100\% & Sangat Efektif \\
$\mathbf{9 0}-\mathbf{1 0 0 \%}$ & Efektif \\
$\mathbf{8 0}-\mathbf{9 0 \%}$ & Cukup Efektif \\
$\mathbf{6 0}-\mathbf{8 0 \%}$ & Kurang Efektif \\
Kurang dari 60\% & Tidak Efektif \\
\hline
\end{tabular}

Sumber: Saputro, dkk (2016)

\section{Hasil Penelitian}

\section{Gambaran Umum}

Kabupaten Lamongan terletak di provinsi Jawa Timur, Indonesia dan ber-ibu kota di Lamongan. Letak Kabupaten Lamongan tidak jauh dari Kabupaten Gresik yang sekaligus sebagai batas timur, Kabupaten Mojokerto dan Kabupaten Jombang merupakan batas selatan kabupaten Lamongan, Kabupaten Bojonegoro dan Kabupaten Tuban di barat, serta Laut Jawa di sebelah utara. Pusat pemerintahannya berjarak +- $50 \mathrm{~km}$ sebelah barat Kota Surabaya, ibu kota Provinsi Jawa Timur. Kabupaten Lamongan merupakan salah satu wilayah yang masuk dalam kawasan metropolitan Surabaya, yaitu Gerbang kertosusila.

\section{Sejarah Badan Pendapatan Daerah}

Sebagaimana "Peraturan Pemerintah Nomor 41 Tahun 2007 tentang Organisasi Perangkat Daerah dan Peraturan Menteri Dalam Negeri Nomor 57 Tahun 2007 tentang petunjuk teknis penataan organisasi perangkat daerah", maka Pemerintah Kabupaten diberikan kewenangan untuk membentuk Perangkat Daerah sesuai kebutuhan dan potensi daerah yang bersangkutan.

Berdasarkan peraturan perundang-undangan diatas maka Pemerintah Kabupaten Lamongan telah membentuk Badan Pendapatan Daerah dengan "Peraturan Daerah Kabupaten Lamongan Nomor 05 Tahun 2016 tentang Pembentukan Susunan Perangkat Daerah Kabupaten Lamongan yang ditindaklanjuti dengan Peraturan Bupati Lamongan Nomor 84 Tahun 2016 
Tentang Kedudukan, Susunan Organisasi, Tugas dan Fungsi, Serta Tata Kerja Badan Pendapatan Daerah Kabupaten Lamongan". Dalam melaksanakan Kedudukan, tugas pokok dan fungsi Badan Pendapatan Daerah merupakan unsur pelaksana otonomi daerah dan mempunyai tugas : "Melaksanakan Kewenangan Urusan Keuangan Di Bidang Pendapatan Daerah“

\section{Strategi Pajak Bumi dan Bangunan Kabupaten Lamongan}

Dalam pemungutan Pajak Bumi dan Bangunan pemerintahan mempunyai strategi yaitu sebagai berikut :

1. Setelah cetak masal Surat Pemberitahuan Pajak Terutang (SPPT) Pajak (PBB) Perdesaan dan Perkantoran (Pajak PBB-P2) segera didistribusikan dikecamatan lalu diteruskan ke desa. Yang pelaksanaanya dibantu oleh petugas UPT (unit pelayanan terpadu/unit pelayanan teknis) dikecamatan.

2. Untuk PNS baik lingkup pemkab maupun dikecamatan diadakan bulan pemungutan dengan tujuan memberikan contoh kepada masyarakat untuk segerah memenuhi kewajiban membayar pajak khususnya PBB perdesaan dan perkantoran.

3. Mengadakan pertemuan UPT kecamatan setiap bulan sekali untuk kooedinasi pemasukan pajak (PBB)-P2

4. Monotoring kekecamatan sampai seberpa jauh SPPT sampai ditanggan masyarakat dan pembayaranya.

5. Untuk memperlancar dan mempercepat pemasukan pajak (PBB)-P2. Tiap desa dibentuk beberapa rayon

6. Untuk pembayaran pajak (PBB)-P2 Kabupaten Lamongan bekerja sama dengan Bank Jatim Kabupaten Lamongan.

\section{Target dan Realisasi Penerimaan Pajak Bumi dan Bagunan di Kabupaten Lamongan tahun 2014-2018.}

Target PAJAK (PBB) di Kabupaten Lamongan pada Badan Pendapatan daerah tahun 2014-2018 adalah sebagai berikut :

Tabel 1

\begin{tabular}{|c|c|c|}
\hline No & Tahun & Target \\
\hline 1 & 2014 & 12.992 .807 .327 .00 \\
\hline 2 & 2015 & 16.142 .986 .226 .00 \\
\hline 3 & 2016 & 18.000 .000 .000 .00 \\
\hline 4 & 2017 & 22.750 .000 .000 .00 \\
\hline 5 & 2018 & 28.000 .000 .000 .00 \\
\hline
\end{tabular}

Realisasi Penerimaan Pajak Bumi dan Bangunan dikabupaten lamongan pada Badan Pendapatan daerah pendapatan daerah tahun 2014-2018 adalah sebagai berikut: 
Tabel 2

\begin{tabular}{ccc} 
Realisasi Penerimaan PAJAK (PBB) Tahun 2014-2018 \\
\cline { 2 - 3 } No & Tahun & Realisasi \\
\hline $\mathbf{1}$ & 2014 & 18.990 .218 .738 .00 \\
$\mathbf{2}$ & 2015 & 18.973 .878 .519 .00 \\
$\mathbf{3}$ & 2016 & 19.100 .114 .134 .00 \\
$\mathbf{4}$ & 2017 & 21.281 .077 .637 .00 \\
$\mathbf{5}$ & 2018 & 28.040 .863 .988 .00 \\
\hline
\end{tabular}

\section{PEMBAHASAN}

Perhitungan efektivitas dilakukan dengan cara membandingkan antara realisasi penerimaan pajak bumi dan bangunan dengan target penerimaan pajak (PBB) yang ditetapkan oleh Pemerintah Kabupaten Lamongan. Berdasarkan tabel berikut diatas menunjukan bahwa secara keseluruhan penerimaan pajak bumi dan bangunan dikabupaten lamongan tahun 2014-2018 sudah mencapai target yg telah ditetapkan. Dalam lima tahun tersebut diatas ada dua tahun yang masih menjadi pajak pusat yaitu pada tahun 2014,2015, Dan beralih menjadi pajak daerah sejak tahun 2018. secara keseluruhan dapat diketahui bahwa terdapat satu tahun dimana tahun tersebut mendapat kreteria sangat efektif tapi dengan presentasi paling rendah yaitu dengan $93,54 \%$ pada tahun 2017 . Karena pada masa tersebut pajak bumi dan bangunan sedang mengalami peralihan yaitu dari pusat ke daerah, dimna pada saat peralihan tersebut target pajak bumi dan bangunan mengalami kenaikan yg cukup tinggi. Sementara pemerintah daerah belum siap saat menghadapi terjadinya peralihan tersebut akibanya target yang telah ditetapkan tidak bisa dicapai dengan baik. sedangkan pada tahun lainya mendapat kreteria sangat efektif dengan pesentase 146,16\% ditahun 2014, 117,54\% ditahun 2015, $106,11 \%$ ditahun 2016 dan presentase 100,15\% ditahun 2017. Sehingga dapat disimpulkan bahwa penerimaan pajak bumi dan bangunan pada saat masih menjadi pajak pusat dan telah beralih menjadi pajak daerah secara keseluruhan pada tahun-tahun tersebut diatas adalah sangat efektif dari tahun ke tahun. Berdasarkan hasil analisis efektifitas penerimaan pajak bumi dan bangunan dikabupaten lamongan terhadap peningkatan pendapatan asli daerah kabupaten lamongan telah berhasil dalam merealisasikan pajak bumi dan bangunan atau dapat mencapai target pajak bumi dan bangunan yang telah ditetapkan.

\section{Hambatan-hambatan dalam meningkatkan tingkat efektifitas penerimaan pajak (PBB) di kabupaten lamongan}

Dalam suatu organisasi yang sukses bukan berarti tanpa ada suatu hambatan. sama halnya dengan pemungutan pajak bumi dan bangunan selalu mengalami hambatan pada saat pemunggutan dlakukan oleh petugas pemungut pajak, hambatan terjadi baik dari petugas pemungut maupun dari wajib pajak tersebut.

Hambatan yang terjadi dalam pelaksanaan pemungutan pajak (PBB) di Kabupaten Lamongan adalah sebagai berikut :

Bisman (Bisnis dan Manajemen): The Journal Of Business and Management 
1. Sulit ditemuinya tempat tinggal WP (wajib pajak). Ini biasa terjadi karena WP (wajib pajak) sedang berada diluar kota atau WP (wajib pajak) telah berpindah tempat tinggal pada saat pemberian SPPT. akibatnya pemerintah kesulitan untuk mecari tempat tinggal wajib pajak tersebut.

2. Kurangya kesadaran masyarakat dalam membayar pajak khususnya pajak bumi dan bangunan dikabupaten lamongan.

Dalam hal ini biasanya disebabkan karena tingkat pendidikan yang rendah pada lingkungan tersebut, sehingga mereka tidak menyadari bahwa pajak yang mereka bayar tidak lain untuk kebaikan wajib pajak sendiri.

3. SPPT (surat pemberitahuan pajak terutang) sudah berpindah tangan Misalnya : Wajib pajak A menjual asetnya pada B tanpa disertai sertifikat atau data asli lainya yang telah didapat dari pemerintah daerah setempat. sehingga pada saat pemungutan dlakukan oleh petugas pemungut pajak, petugas kesulitan untuk mengatasinya karena asset tersebut bukan beratas nama pemilik yang telah membelinya dari wajib pajak pertama.

4. SPPT (surat pemberitahuan pajak terutang) pajak bumi dan bangunan belum dipecah.

Dalam hal ini biasanya wajib pajak pertama mempunyai asset dengan satu SPPT kemudian membagi asset tersebut kepada beberapa saudarahnya tanpa melapor pada pemerintah daerah sehingga asset tersebut diberikan tanpa adanya sertifikat yang sah dari pemerintah daerah.

5. Kondisi ekonomi yang kurang memungkinkan.

Masyarakat pada kabupaten lamongan mayoritas bermata pencarian sebagai petani untuk mencukupi kebutuhan-kebutuhannya, serta membayar pajak khususnya pajak bumi dan bangunan. Dalam hal ini biasanya yang menjadi kendala dalam membayar pajak bumi dan bagunan adalah :

a. Terjadi bencana alam

b. Besarnya SPPT bagi ekonomi bawah

Upaya-upaya pemerintah dalam mengatasi hambatan-hambatan yang terjadi dalam pemungutan pajak (PBB)

1. Pemerintah bekerjasama dengan keordinator rayon desa.

Dalam hal ini biasanya pemerintah meminta agar coordinator rayon desa segerah menghubungi pemilik SPPT tersebut memalui saudara atau orang terdekat lainya.

2. Mengadakan sosialisasi

Sosialisasi ini diadakan dengan tujuan untuk memberi informasi bagi yang telah melunasi pajaknya khususnya pajak bumi dan bangunan supaya lebih tepat waktu dalam membayar pajak tersebut. dan bagi masyarakat yang belum memahami pentingnya membayar pajak tersebut, diharapkan setelah diadakanya sosialisasi oleh pemerintah masyarakat atas kelalaianya yang perna dilakukan dalam membayar pajak khususnya pajak bumi dan bangunan.

3. Mencari informasi dan menghubungi wajib pajak pertama

Dalam permasalahan ini pemerintah biasanya bekerjasama dengan keordinator rayon desa setempat dalam mencari informasi tentang tempat tinggal wajib pajak pertama melalui wajib pajak yang telah membeli asset 
dari wajib pertama tersebut. Meskipun wajib pajak kedua telah membelinya secarah sah namun juka tidak disertai dengan sertifikat yang terdaftar dipemerintahan maka wajib pajak kedua juga tidak memiliki hak untuk membayar SPPT tersebut.

4. Melapor pada pemerintah daerah setempat.

Untuk permasalahan SPPT (surat pemberitahuan pajak terutang) yang telah dipecah, biasanya yang dilakukan oleh petugas pemungut pajak adalah memberi solusi pada masing-masing wajib pajak yang telah diberi asset tersebut untuk segerah melapor pada pemerintah agar masing-masing wajib pajak diberikan SPPT (surat pemberitahuan pajak terutang) sesuai dengan asset yang telah mereka terima dari wajib pajak pertama. agar pembayaran pajak dapat lebih mudah dilakukan.

5. Pemerintah akan memaklumi dan akan memberikan kesempatan.

Untuk bencana alam yang terjadi pada suatu desa pemerintah akan memberi keringanan pada masyarkat dengan cara mengundur penarikan pajak bumi dan bangunan. akan tetapi masyarakat juga harus membayar denda yang telah ditetapkan oleh pemerintah akibat keterambatanya dalam membayar pajak bumi dan bangunan tersebut, dan denda yang telah ditetapkan tersebut bisa dibayar pada tahun berikutnya pada saat penarikan pajak bumi dan bangunan dilakukan.

\section{KESIMPULAN DAN SARAN}

\section{Simpulan}

Berdasarkan hasil penelitian dan pembahasan sebelumnya maka penulis mengambil kesimpulan, yaitu

1. Penerimaan pajak (PBB) di Kabupaten Lamongan sudah sangat efektif, dilihat dari Tahun 2014-2018 dengan presentase yang ada.

2. Menurut penulis pada saat melakukan pemungutan pajak (PBB) ditemukan ada beberapa hambatan yang terjadi saat pemungutan berlangsung. Dan hambatan tersebut terjadi kebanyakan dari masyarakat sendiri, dikarenakan masih ada banyaknya masyarakat yang belum mempunyai kesadaran untuk membayar utang pajaknya khususnya pajak (PBB) di Kabutaen Lamongan. Hal ini dapat dibuktikan bahwa masih banyak masyarakat yang lalai atas pajak bumi dan bangunan, kebanyakan masyarakat itu menganggap remeh atas asset yang mereka miliki.

3. Upaya Pemerintah Daerah menurut penulis sudah sangat maksimal, karena Pemerintah telah dapat mengatasi hambatan-hambatan yang ada dengan sebaik-baiknya. Meskipun masih ada hambatan disetiap tahunnya pada saat pemungutan pajak khususnya pajak bumi dan bangunan dilakukan akan tetapi hambatan tersebut dapat diatasi dengan baik oleh Pemerintah Daerah Kabupaten Lamongan. Seperti yang telah dijelaskan diatas bahwa hambatan yang banyak terjadi adalah kurangnya kesadaran masyarakat dalam melunasi pajak bumi dan bangunan. 


\section{Saran}

Dilihat dari data realisasi pada tahun 2014-2018 Badan Pendapatan daerah kabupaten Lamongan tersebut bisa terbilang sangat efektif dilihat dari nilai presentasinya. Akan tetapi pada tahun 2017 pemungutan pajak bumi dan bangunan Lamongan terbilang sangat efektif tetapi dengan presentase paling rendah. Maka penulis memberikan masukan kepada Bapenda kabupaten Lamongan agar bisa memberikan peningkatan dikemudian hari “

1. Penulis mengharapkan Bapenda kabupaten Lamongan lebih sering mengadakan pelatihan atau sejenisnya, dengan tujuan agar pada saat terjadinya kendala atau yang lainnya pemerintah daerah kabupaten Lamongan sudah sangat siap dalam menghadapi berbagai permasalahan yang ada. Dan pemerintah daerah dapat mempertahankan presentase yang sangat dari tahun ke tahun.

2. Dalam menghadapi masyarakat yang kurang mempunyai kesadaran dalam membayar atau melunasi pajak khususnya pajak bumi dan bangunan penulis menyarankan kepada petugas pemungut pajak agar lebih sering dalam mengadakan pertemuan atau sosialisasi kepada masyarakat yang dikiranya kurang patuh dalam membayar pajak (PBB) dengan tujuan agar masyarakat tersebut supaya lebih patuh dalam melunasi utang pajaknya dengan tepat waktu.

3. Penulis menyarankan agar pemerintah daerah memperkuat hubungan baik dari kelurahan dan kecamatan tersebut, agar kendala yang ada dapat diatasi bersama, dan penyetoran seperti bisa lebih maksimal. 


\section{DAFTAR PUSTAKA}

Anggraeni, Dian (2011), Analisis Strategi Pemungutan Pajak Bumi dan Bangunan (pajak PBB) di Kota Surabaya Terhadap Peningkatan Realisasi Target Penerimaannya, Jurnal Perpajakan, Volume 22 No.19

Ariyani, Devi (2010), Analisis Tingkat Perkembangan Penerimaan Pajak Bumi dan Bangunan di Badan Pendapatan Pengelolaan Keuangan dan Aset (DPPKA) Kota Surakarta, Jurnal Perpajakan, Vol 4 No.36

Astutik, Tenny Putri, dkk (2012), Efektifitas Pemungutan Pajak Bumi dan Bangunan Untuk Meningkatkan Pendapatan Asli Daerah, Jurnal Administrasi Publik (JAP), Vol. 2 No.1 Hal 47-52

Damayanti, Ni Putu Dian (2014), Analisis Efektifitas dan Kontribusi Penerimaan PAJAK (PBB) Terhadap PAD Kota Denpasar, Jurnal Ekonomi dan Bisnis, Vol 7 No.09

Dewi, Indah Kusuma (2012), Analisis Biaya Pemungutan Pajak Bumi dan Bangunan Sektor Pedesaan dan Perkotaan Setelah Diserahkan Ke Daerah, Skripsi, Fakultas Ilmu Sosial dan Ilmu Politik, Universitas Indonesia, Jakarta.

Dewi, Olivia dan Widuri, Retnaningtyas (2013), Faktor-Faktor Yang Mempengaruhi Keberhasilan Penerimaan Pajak Daerah Kota Tarakan, Jurnal Tax \& Accounting Review Vol. 3 No. 2

Efferin, Sujoko, dkk (2012), Metode Penelitian Akuntansi. Cetakan Pertama, Graha Ilmu, Yogyakarta.

Fahruddin, Pasolo (2015), The Tendency of Revenue and Levies Contribution to the PAD Jayapura Before and After The Law No. 28 of 2009, Journal of Social and Development Sciences (ISSN 2221-1152) Vol. 6No. 4 pp 45-51 December 2015

Haldenwang, Chriantian Von (2015), The Political Cost of Local Revenue Mobilisation : Decentralisation of the Property Tax in Indonesia, Journal of Empirical Research Carried Out In Indonesia

Handayani, Witiya Tri (2014), Analisis Faktor-Faktor Yang Mempengaruhi Realisasi Penerimaan Pajak Bumi dan Bangunan Pada Kecamatan Jabres Kota Surakarta, Jurnal Perpajakan, Vol. 2 No.3 Hal 224-237.

Ferdiansyah, Fery, Delamat, Harun dan Aryanto (2018) Analisis Efektivitas Penerimaan Pajak Daerah, Retribusi Daerah Dan Kontribusinya Terhadap Peningkatan Pendapatan Asli Daerah (Studi Pada Badan Pengelolaan 
Pajak Daerah Kota Palembang 2012-2016). Undergraduate thesis, Sriwijaya University.

Hermansyah, Andi Abdillah (2015), Efektifitas Pemungutan Pajak Bumi dan Bangunan Perdesaan Perkotaan (Pajak Bumi dan Bangunan) P2) Di Dispenda Kota Makassar, Skripsi, Fakultas Ilmu Sosial dan Ilmu Politik, Universitas Hasanudin, Makassar

Mardiasmo (2016), Perpajakan. Edisi Terbaru 2016, ANDI. Yogyakarta.

Prathiwi, Ida, Apsari, Ayu Metha dan Nerawat,i Nyoman Trisna (2015), Analisis Strategi Penerimaan Pajak Bumi dan Bangunan Pedesaan dan dan Perkotaan (Pajak Bumi dan Bangunan P2) Serta Efektifitas Penerimaannya di Pemerintah Kota Denpasar, Jurnal Akutansi, Vol XII No.12

Putri, Istikhomah Kusuma (2016), Evaluasi Penerimaan Pajak Bumi dan Bangunan Pasca UU PDRD (UU No. 28 Tahun 2009), Naskah Publikasi Ekonomi Bisnis

Rahayu, Siti Kurnia (2010), Perpajakan Indonesia. Graha Ilmu, Yogjakarta.

Rahmatika, Alvy (2013), Studi Komparatif Efektivitas Pengelolaan Pajak Bumi dan Bangunan (Pajak Bumi dan Bangunan) Sebelum dan Sesudah Berlakunya Undang-Undang No.28 Tahun 2009 pada Kabupaten Kediri, Jurnal Perpajakan, Vol 3 No.20

Resmi, Siti (2017), Perpajakan Teori \& Kasus. Edisi Ke 10, Salemba Empat, Jakarta.

Saputro, Rudi, Sudjana Negah (2016), Efektifitas Penerimaan Pajak Bumi dan Bangunan Perdesaan dab Perkotaan (Pajak Bumi dan Bangunan P2) Terhadap Peningkatan Penerimaan Pendapatan Asli Daerah (PAD), Jurnal Perpajakan, Vol 07 No.10

Sasana, Hadi (2001), Analisis Faktor-Faktor Yang Mempengaruhi Penerimaan Pajak Bumi dan Bangunan (PBB), Jurnal Perpajakan. Volume 16 No. 200

Suandy, Erly (2005), Hukum Pajak, Edisi Ketiga, Jakarta : Salemba Empat.

Suandy, Erly (2013), Hukum Pajak. Edisi Kelima. Salemba Empat, Jakarta Selatan

Sugiyono (2015), Statistika Untuk Penelitian. Cetakan Ke-26, Alfabeta : Bandung

Sutedi, Andrian (2013), Hukum Pajak. Cetakan kedua, Sinar Grafika, Jakarta.

Bisman (Bisnis dan Manajemen): The Journal Of Business and Management 
Tarigan, Kharisma Wanta (2013), Analisis Efektifitas dan Kontribusi Pajak Bumi dan Bangunan Terhadap Penerimaan Pajak di KPP Pratama Kota Manado, Jurnal EMBA, Vol.1 No. 3 Edisi Juni 2013 282-291

Utiarahman, Nur Riza (2016), Analisis Efektifitas dan Kontribusi Penerimaan Pajak Bumi dan Bangunan Perdesaan Perkotaan (Pajak Bumi Dan Bangunan P2) Terhadap Pendapatan Asli Daerah (PAD) Kota Tomohon, Jurnal Berkala Ilmiah Efisiensi, Volume 16 No.02

Waluyo (2014), Akuntansi Pajak. Edisi Ke Lima, Salemba Empat, Jakarta.

Wulansepty, Dinar Ratna dan Mildawati Titik (2014), Strategi Pemungutan Pajak Bumi dan Bangunan Kota Surabaya Terhadap Realisasi Target Penerimaan, Jurnal Ilmu \& Riset Akuntansi. Vol. 3 No.1

\section{Peraturan Perundang-Undangan:}

Undang-Undang Republik Indonesia Nomor 12 Tahun 1985 jo. Undang-Undang Republik Indonesia Nomor 12 Th 1994 tentang Pajak Bumi Dan Bangunan

Undang-Undang Republik Indonesia Nomor 28 Tahun 2009 tentang Pajak Daerah Dan Retribusi Daerah

Peraturan Pemerintah Nomor 41 Tahun 2007 tentang Organisasi Perangkat Daerah

Peraturan Menteri Dalam Negeri Nomor 57 Tahun 2007 tentang Petunjuk Teknis Penataan Organisasi Perangkat Daerah

Peraturan Daerah Kabupaten Lamongan Nomor 05 Tahun 2016 tentang Pembentukan Susunan Perangkat Daerah Kabupaten Lamongan

Peraturan Bupati Lamongan Nomor 84 Tahun 2016 Tentang Kedudukan, Susunan Organisasi, Tugas dan Fungsi, Serta Tata Kerja Badan Pendapatan Daerah Kabupaten Lamongan

Bisman (Bisnis dan Manajemen): The Journal Of Business and Management 